\title{
The Health Risk Associated with Chronic Diseases in Villages with High Arsenic Levels in Drinking Water Supplies
}

\author{
Orhan Gunduz $^{1}\left(\mathbb{D} \cdot\right.$ Coskun Bakar $^{2} \cdot$ Celalettin Simsek $^{3} \cdot$ Alper Baba $^{4} \cdot$ \\ Alper Elci ${ }^{1} \cdot$ Hakan Gurleyuk ${ }^{5} \cdot$ Merdiye Mutlu' $^{6}$ Ayse Cakir ${ }^{6}$
}

Received: 5 October 2016/Revised: 25 November 2016/Accepted: 26 November 2016/Published online: 3 December 2016

(C) Springer Science+Business Media Dordrecht 2016

\begin{abstract}
This study is intended to compare and assess the distribution and possible causes of current chronic diseases in villages with high arsenic levels in drinking water supplies. It is a cross-sectional epidemiological research that analyzes the frequency and underlying risk factors of chronic diseases in villages with varying levels of arsenic exposure through drinking water. Sample space of study included 1003 individuals, 614 of whom were from villages with high arsenic levels in drinking water and remaining 389 were from two control villages with belowlimit arsenic levels in drinking water. While nutritional habits and living environments of two groups were similar, cigarette smoking and alcohol use were higher in villages with low arsenic levels. Mini mental state examination test results in $60+$ age group were lower in villages with high arsenic levels. Although no statistically significant differences were detected in chronic disease occurrence between the groups, the number of cases was higher in villages with higher percentage of cigarette smoking and alcohol use. Moreover, cases of lung, colon, and stomach cancers were
\end{abstract}

Orhan Gunduz

orhan.gunduz@deu.edu.tr

1 Department of Environmental Engineering, Dokuz Eylul University, Izmir, Turkey

2 Department of Public Health, School of Medicine, Canakkale Onsekiz Mart University, Canakkale, Turkey

3 Torbali Vocational School, Dokuz Eylul University, Izmir, Turkey

4 Department of Civil Engineering, Izmir Institute of Technology, Izmir, Turkey

5 Applied Speciation and Consulting LLC, Bothell, WA, USA

6 Graduate School of Natural and Applied Sciences, Dokuz Eylul University, Izmir, Turkey higher in villages with high arsenic levels in drinking water supplies.

Keywords Groundwater · Arsenic · Simav · Chronic diseases · Household survey

\section{Introduction}

Presence of high arsenic levels in drinking water supplies is a proven human health risk. The World Health Organization (WHO) reports that more than 200 million people on earth is consuming drinking water that is above the standard level of $10 \mu \mathrm{g} / \mathrm{L}$ (WHO 2011). Arsenic problem is mostly dominant in the countries of southern Asia and Latin America. According to George et al. (2014), more than 4.5 million people are exposed to high levels of arsenic in Latin America. Chronic exposure to arsenic is among the etiological risk factors of a number of diseases including but not limited to skin, bladder, lung, and liver cancers as well as a number of chronic diseases such as cardiovascular disease and diabetes (Rahman et al. 1998; Chou and De Rosa 2003; Meliker et al. 2007; States et al. 2009; Hughes et al. 2011; Saint-Jacques et al. 2014). It is known that more than one risk factor is effective in the etiology of chronic diseases such as cardiovascular diseases, diabetes, and cancers. Thus, studies related to these diseases typically not only focus on the most significant target risk factor but also consider the potential influence of additional risk factors such as cigarette smoking, physical inactivity, obesity, alcohol use, and unhealthy diets that might be influential on the occurrence of these diseases (WHO 2015).

Long-term exposure to arsenic through drinking water influences gastrointestinal, dermal, neural, renal, hepatic, 
hematological, cardiovascular, respiratory, and ophthalmic systems via acute and subacute toxicity (Chen 2010). Among these systems, gastrointestinal system is the one that is most influenced under high dose conditions (Chen 2010). Acute gastrointestinal syndrome starts with a metallic or garlic-like taste and creates dryness in mouth, burn in lips, and dysphagia. Acute toxicity can result in symptoms that lead to shock, multi-organ deficiency, and death (Chen 2010). Nevertheless, acute arsenic toxicity is quite a rare situation nowadays unless direct poisoning occurs. On the contrary, occurrence of high arsenic levels in drinking water resources is a commonly observed phenomenon in various parts of the world and is the most significant cause of chronic exposure, which is known to influence multiple organs and cause a number of diseases such as gastrointestinal system cancers, lung cancers, and diabetes (Chen 2010; Saint-Jacques et al. 2014).

Numerous research on the effects of arsenic on human health is available in the literature (Chou and De Rosa 2003; States, et al. 2009; Chen 2010; Gong et al. 2011; Guo 2011; George et al. 2014). In a study conducted in Taiwan, Guo (2011) has found a positive correlation between arsenic levels of above $640 \mu \mathrm{g} / \mathrm{L}$ and bladder cancer occurrence in man and women. Chiou et al. (2001), on the other hand, have reported that high arsenic levels in drinking water increase the occurrence of urinary system cancers 2.05 (95\% CI 1.22-3.24) times. In a study conducted in Chile, Liaw et al. (2008) have reported that high arsenic levels results in an increase in child deaths due to liver cancer. Similarly, another study in Chile reported that over $200 \mu \mathrm{g} / \mathrm{L}$ arsenic levels in drinking water increases lung cancer risk 8.0 (95\% CI 1.7-52.3) times, whereas this risk was further increased to 32.0 (95\% CI 7.22-198.0) times when there is smoking history in the patient (Ferreccio et al. 2000). In an epidemiological review by States et al. (2009), it was reported that the mortality rates due to high blood pressure, carotid atherosclerosis, ischemic heart disease, and vascular diseases increase in areas where groundwater arsenic levels exceed $300 \mu \mathrm{g} / \mathrm{L}$ level. Moreover, Gong et al. (2011) have focused on the cognitive function impacts of arsenic and reported that mini mental state examination scores were significantly lower in areas where arsenic levels in groundwater were above $10 \mu \mathrm{g} / \mathrm{L}$. The study group in this study had an age range of 40-94 and an average age of 61.6. Gong et al. (2011) further reported that arsenic exposure resulted in retardation in neurobehavioral development in animal experiments. Thus, arsenic exposure is believed to influence neurocognitive functions in gestational period.

Arsenic problem in the Kütahya Province of Turkey was recently detected and reported to be a major problem creating human health risks (Dogan et al. 2005; Gunduz et al. 2010, 2012). Dogan et al. (2005) determined the presence of skin lesions in the Emet district of Kütahya and attributed these problems to extremely high arsenic levels in local groundwater resources. Gunduz et al. (2010), on the other hand, studied the overall groundwater quality in Simav district of Kütahya and determined elevated levels of arsenic presence. Simav Plain is a graben area near the Simav district of Kütahya province and is situated in an area of active tectonism with major alteration zones and geothermal resources. An average arsenic concentration of $99 \mu \mathrm{g} / \mathrm{L}$ was reported by Gunduz et al. (2010) where maximum levels reached $561 \mu \mathrm{g} / \mathrm{L}$. In the same study, 221 cases of death between 1998 and 2005 period were analyzed and cardiovascular diseases (45.2\%) were found to be the primary cause of death, followed by cancers $(15.8 \%)$ and respiratory system illnesses $(5.7 \%)$. Among all neoplasms, lung cancers were the most predominant (34.1\%) cancer type, which was followed by stomach (20\%), colon and prostate $(20 \%)$, liver $(17.1 \%)$, and other (including skin) (8.8\%) cancers (Gunduz et al. 2010). Gunduz et al. (2012) further studied the area and found that the arsenic in plain's groundwater is mostly of the more toxic arsenite $\left(\mathrm{As}^{+3}\right)$ species.

Although there is substantial amount of information present on elevated arsenic presence for many parts of Turkey, a systematic research on public health problems associated with long-term arsenic exposure is scarce. In particular, no study was found on the assessment of the risk factors influential on the occurrence of arsenic-related systemic diseases. Thus, the main motivation of this study is to provide a quantitative link between arsenic exposure and the occurrence of systemic diseases in an area with moderately long exposure to elevated arsenic levels in drinking water. The study area included three villages (Çitgöl, Boğazköy, and Gölköy) of Simav district with above standard arsenic levels in drinking water supplies where minimum 20 years of exposure took place as well as two control villages (Demirciköy and Öreyler) from the same area with below standard arsenic exposure history. As a result, a quantitative comparison of the distribution of existing chronic diseases in these villages is performed to demonstrate the relationship between arsenic exposure and chronic diseases.

\section{Methods}

\section{Study Area}

The study area of this research is the Simav Plain situated in Western Anatolia, Turkey (Fig. 1). Simav Plain is a graben depression with complex geology and active tectonics. Previous research conducted in the study area has revealed the presence of elevated levels of arsenic in 


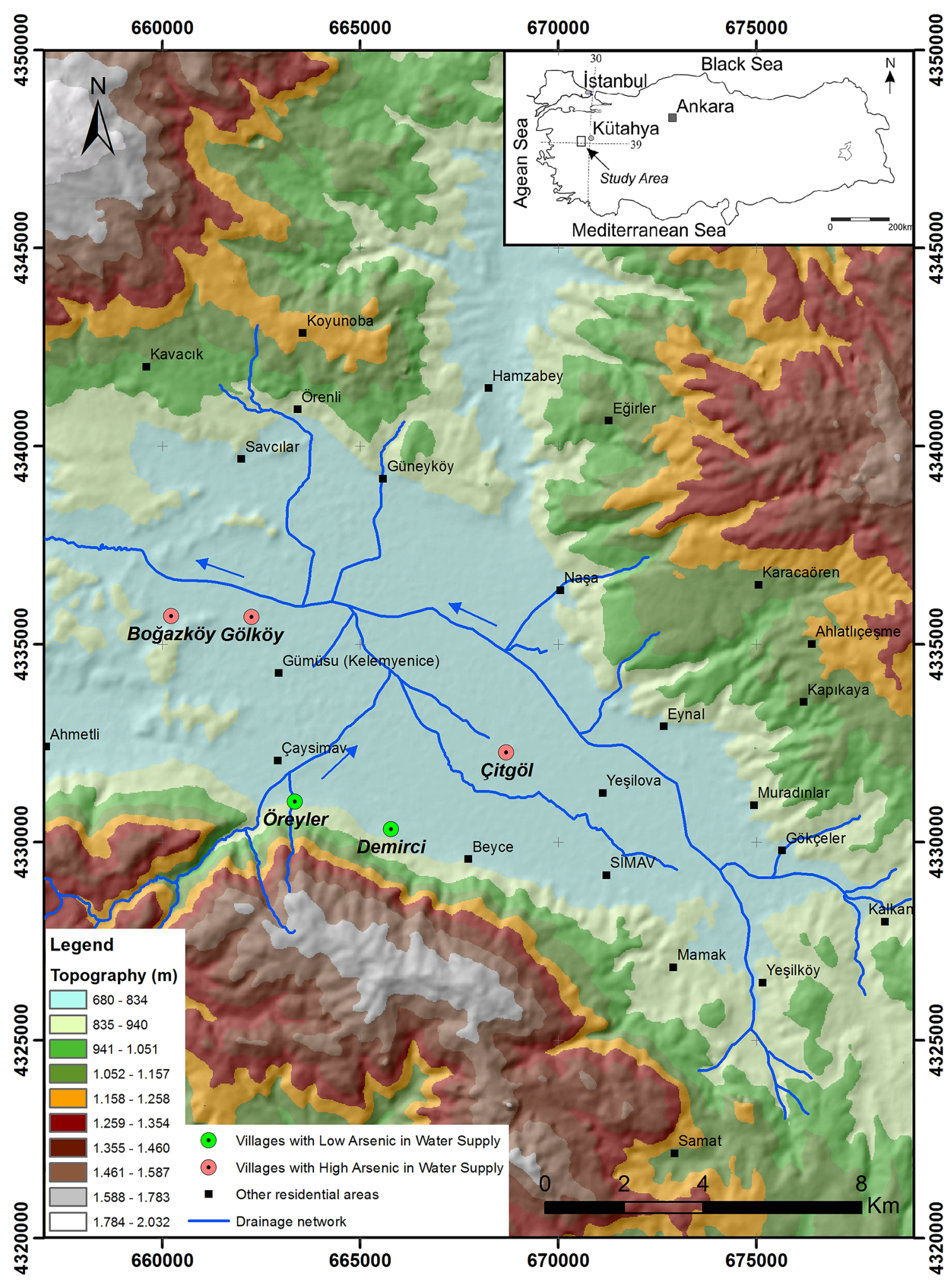

Fig. 1 Study area

surface and subsurface waters of the plain (Gunduz et al. 2010; Simsek and Gunduz 2007). Further research in the area has revealed the fact that the alluvial material that forms the major groundwater containing aquifer in the plain was extremely rich in arsenic (Gunduz et al. 2012). The results of the geochemical investigations on subsurface 
formations conducted at 21 boreholes that were drilled throughout the plain have shown that arsenic in Simav plain alluvial layer ranged between 7.1 and $833.9 \mathrm{ppm}$ with an average of $48.99 \mathrm{ppm}$ and a standard deviation of 80.21 ppm (Gunduz et al. 2012). When compared with the average value of $2.0 \mathrm{ppm}$ arsenic in upper continental crust (Wedepohl 1995), it was clear that the study area was a hot spot and had elevated risk associated with human exposure to arsenic. Further monitoring studies conducted in the area verified the above average arsenic presence in the groundwater of the alluvial plain based on the results of wet and dry season sampling programs completed during April and September 2011. Accordingly, arsenic levels in groundwater ranged between 1 and $1025.6 \mu \mathrm{g} / \mathrm{L}$ with an arithmetic average of $234.9 \mu \mathrm{g} / \mathrm{L}$ and a standard deviation of $261.8 \mu \mathrm{g} / \mathrm{L}$ during April 2011 monitoring program; and between 1.3 and $1123.7 \mu \mathrm{g} / \mathrm{L}$ with an arithmetic average of $256.2 \mu \mathrm{g} / \mathrm{L}$ and a standard deviation of $288.9 \mu \mathrm{g} / \mathrm{L}$ during September 2011 monitoring program (Gunduz et al. 2012). As the national limit for arsenic in drinking water is $10 \mu \mathrm{g}$ / L, it can easily be concluded that the arsenic level in Simav plain groundwater is well beyond the limit value. From a public health point of view, this information was sufficient to initiate further studies to understand the potential health implications of this elevated arsenic presence in plain's groundwater which was used for domestic and irrigational water supply. From this token, this study is conducted as a cross-sectional epidemiological research that aimed to analyze the frequency of chronic diseases in villages with high arsenic levels in drinking water supplies and to characterize the potential influence of other risk factors that might be influential on the occurrence of these diseases.

\section{The Type and Hypothesis of the Study}

This study is conducted as a cross-sectional epidemiological study. Its main objective is to determine and compare the chronic disease prevalence of the villages with and without elevated arsenic levels in their drinking water resource. Accordingly, the hypothesis of the study is formulated as follows:

$\mathbf{H}_{\mathbf{0}}$ There exist no differences of chronic disease prevalence between villages with high arsenic levels in drinking water resources (Gölköy, Boğazköy, and Çitgöl) and villages with low arsenic levels in drinking water resources (Öreğler and Demirciköy).

$\mathbf{H}_{1}$ There are differences of chronic disease prevalence between villages with high arsenic levels in drinking water resources (Gölköy, Boğazköy, and Çitgöl) and villages with low arsenic levels in drinking water resources (Öreğler and Demirciköy).

\section{Population and Sample Size}

The population of this study comprised all inhabitants of the villages of Gölköy, Boğazköy, Çitgöl, Öreyler, and Demirciköy with an age of 18 and above. Based on the records of the Civil Registration and Nationality Office of the District of Simav, the population of the study was 5178 people $(18+$ population) who lived in these five villages in the year 2010. Of this total, 3264 individuals lived in three villages (Boğazköy, Gölköy, and Çitgöl) where drinking water supply contained above standard arsenic levels and remaining 1914 individuals lived in two villages (Demirciköy and Öreyler) with below standard level of arsenic in drinking water supplies. The arsenic levels that this population was exposed to were measured in a study (Gunduz et al. 2015) parallel to the one presented herein and are given in Table 1.

The number of individuals required in each group of villages (sampling size) was computed separately according to the following formula given by Lemeshow et al. (1990):

$n=\frac{N\left(Z_{1-\alpha / 2}^{2} P(1-P)\right)}{d^{2}(N-1)+Z_{1-\alpha / 2}^{2} P(1-P)}$,

where $\mathrm{n}$ is the sample size; $\mathrm{N}$ is population size; $\mathrm{Z}_{1-\alpha / 2}$ is the number of standard errors from the mean (1.96); $P$ is the anticipated population proportion $(0.5)$; and $\mathrm{d}$ is the absolute precision required on either side of the proportion (0.05). Accordingly, the minimum sample sizes to be reached by the field teams were found to be 344 for the villages with high arsenic in drinking water and 321 for the villages with low arsenic in drinking water. Based on these minimum numbers, the household survey was conducted with a total of 1003 people, of which, 614 lived in villages with high arsenic level (202 in Gölköy, 204 in Boğazköy, and 208 in Çitgöl) and 389 lived in villages with low arsenic level (197 in Öreyler and 192 in Demirciköy) in drinking water supplies.

\section{Research Approach and Sources of Data}

The data collection stage of this study was conducted with voluntary individuals through face-to-face interviews. The data used in the analysis were collected by a group of 7 surveyors in July of 2010 and 2011. The field studies were completed in July 2010 in all villages but Çitgöl. The interviews conducted in Çitgöl were performed in July 2011 due to logistical necessities. During the interviews, household questionnaire forms were filled by questioning individuals from randomly selected houses until a pre-determined sampling size was reached in each village. All the individuals surveyed were local people who lived in these 
Table 1 Arsenic (As) concentrations in the drinking water supplies of the villages studied, 2011, Simav-Kütahya

\begin{tabular}{lllll}
\hline Village names & $\begin{array}{l}\text { As }(\mu \mathrm{g} / \mathrm{L})^{\mathrm{d}} \\
\text { July 2005 }\end{array}$ & $\begin{array}{l}\text { As }(\mu \mathrm{g} / \mathrm{L})^{\mathrm{d}} \\
\text { May 2010 }\end{array}$ & $\begin{array}{l}\text { As }(\mu \mathrm{g} / \mathrm{L})^{\mathrm{d}} \\
\text { April 2011 }\end{array}$ & $\begin{array}{l}\text { As }(\mu \mathrm{g} / \mathrm{L})^{\mathrm{d}} \\
\text { September 2011 }\end{array}$ \\
\hline Demirciköy & No data & 1.3 & 1.3 & 1.3 \\
Öreyler & No data & 1.0 & Not sampled & Not sampled \\
Çitgöl & 27.0 & 42.9 & 37.2 & 64.4 \\
Gölköy-Boğazköy & No data & No data & 318.2 & 331.4 \\
Gölköy-Boğazköy $^{\mathrm{b}}$ & 177.2 & 1812.8 & 876.3 & 605.0 \\
Gölköy-Boğazköy $^{\mathrm{c}}$ & No data & 9.2 & Not sampled & Not sampled \\
\hline
\end{tabular}

${ }^{a}$ Previously used spring (public fountain): Gölköy and Boğazköy villages have used water from this spring during 1984-1997 period

b Previously used well: Gölköy and Boğazköy villages have used water from this borehole during 1997-2008 period. The well is not used since 2009

c New well: Gölköy and Boğazköy villages are currently using the water extracted from this new well since July 2009 that is below the limit value of $10 \mu \mathrm{g} / \mathrm{L}$

d The arsenic measurements were made with inductively coupled plasma mass spectrometer (ICP-MS) technique villages throughout their lives except for possible shortterm travels to outside the study area such as vacation, seasonal jobs. Thus, the surveyed individuals consumed local water resources for the majority of their lives.

The questionnaire comprised two main sections: (i) a household survey that primarily questions the individual's health status and (ii) a verbal autopsy survey that questions the individual for any incidences of death in his/her family or in the village during 2005-2010 period. The results obtained from the first part of the questionnaire were analyzed within the scope of this study to determine the frequency of chronic diseases in villages with high arsenic levels in drinking water supplies and to characterize the potential influence of other risk factors that might be influential on the occurrence of these diseases.

The household survey contained three subsections. In the first section, primary demographic characteristics of the household were questioned. In the second section, a mini mental state examination (MMSE) test was conducted to quantify the individual's cognitive functions. The MMSE test is a general assessment tool implemented in epidemiological studies to detect the dementia-related status of the individual and is used in determining cognitive defects, changes in dementia syndromes, and responses to treatment (Güngen et al. 2002). The test contained five parts including the orientation, verbal recall, visual cognition, attention, and language, which are summed up and evaluated out of a highest score value of 30 . The cut-off line for the presence of dementia and cognitive function defects was set at 23-24 level (Güngen et al. 2002). Finally, the last section of the household survey contained questions that were designed to collect information on the general health status of the surveyed individuals and the social and environmental decisive factors that can influence their health status such as the characteristics of their dwellings and the household, harmful habits, nutritional routines, and physical activity levels. In this section, data on acute and chronic diseases suffered within the past one year, individuals requiring nursing, and incidences of death within the past five years were also questioned. These questions specifically addressed the diseases that were diagnosed with a doctor which require permanent use of medications. The results were then used by a medical doctor to assess the presence of a chronic disease. The information collected from this part of the survey was later referenced according to the ICD-10 coding system.

The heights and weights of all surveyed individuals were measured with two identical sets of scales and meters to determine their obesity status. Height measurements were conducted with bare foot, and body mass index values of all individuals were calculated. An index value of 24.9 and below was considered to be normal weight, and an index value of 25 and above was considered to be overweight or obese.

\section{Individual Arsenic Exposure}

The average individual arsenic exposure via oral route is calculated by using the arsenic concentration of the village the individual resides, the daily water intake of the individual, and the body weight of the individual according to the following formula:

Dose $=\frac{\text { Conc } \times D I}{B W}$,

where Conc is the concentration of arsenic in the water supply $(\mu \mathrm{g} / \mathrm{L}) ; D I$ is the daily water consumption or intake (L/day); and $B W$ is the body weight $(\mathrm{kg})$ of the individual for which the exposure is calculated. The dose computed with this formula corresponds to the average chronic daily 
intake of arsenic via the oral route through drinking water consumption. Other routes of exposure such as dermal intake or intake with food irrigated with arsenic-containing irrigation water are not considered in this study. The arsenic concentration values of the sources used in dose computation are given in Table 1.

\section{Statistical Analysis}

The results of this study were analyzed with the statistical package for the social sciences (SPSS) program upon completion of data quality control. $\chi^{2}$ goodness-of-fit, Student's $t$ test, and variance analysis were used in the statistical analysis of data. For statistical significance, it was assumed that $p<0.05$. The international classification of diseases (ICD-10) coding system of World Health Organization (WHO) was used in this study to group disease symptoms and causes of death.

The Student's $t$ test was used to determine the differences in average consumption of fruit, vegetables, water, tea, and coffee between villages. $\chi^{2}$ analysis was conducted to evaluate the distribution of sex, age, cigarette smoking, alcohol use, mini mental state examination scores, obesity status, and the presence of chronic diseases between villages. Finally, logistic regression analysis was performed to assess the risk factors related to chronic diseases. For this analysis, the dependent variable was considered to be the presence of one or more of chronic diseases including cardiovascular diseases, chronic respiratory diseases, diabetes mellitus and endocrine system diseases, cancers, and gastrointestinal system diseases. The independent variables, on the other hand, were assigned as sex, village, individual arsenic exposure via oral route, obesity, history of chronic disease presence in the family, cigarette smoking and exposure to second hand smoke, salt consumption, and total length of time lived in the village. A backward conditional logistic regression analysis was then conducted with these parameters, and the statistical significance was taken to be $p<0.05$.

\section{Results}

Within the scope of this research, a total of 1003 individuals were surveyed in five villages of Simav district (Table 2). The average age was found to be $53.95 \pm 17.4$. No significant differences in age distribution were found between the two regions of interest $(p>0.05)$. The marital status, education level, and profession held showed similar distributions in these villages (Table 2).

Cigarette smoking was found to be higher in Öreyler and Demirciköy $(p<0.05)$. As shown in Table 3, 23.6\% of all surveyed individuals were found to smoke and only $3.8 \%$ of all smokers were female. Of all women surveyed, $1.9 \%$ still smoke; $3.5 \%$ have quit smoking; and $94.6 \%$ have never smoked before. On the other hand, only $18.4 \%$ of all surveyed males have never smoked during their lives.

Of all the individuals surveyed, $82.7 \%$ have never used alcohol; $5.7 \%$ currently use alcohol; and $11.7 \%$ have used but quit alcohol. Statistically significant differences in alcohol use were detected between the villages $(p<0.05)$. The percentage of individuals who have never used alcohol was higher in Gölköy, Çitgöl, and Boğazköy when compared to Demirciköy and Öreyler.

The results of the mini mental state examination (MMSE) test were used to assess the cognitive and dementia status of the individuals surveyed within the scope of this study. The cut-off line was set at 23 points, and individuals receiving points less than or equal to 23 were considered to be under risk. In the study area, individuals receiving 23 points and less were found to be $50.7 \%$. No statistically significant differences were detected between the villages $(p>0.05)$. However, $53.1 \%$ of the individuals with MMSE score of 23 or less were from villages with high arsenic levels in drinking waters. The ratio was calculated to be $46.9 \%$ in villages with low arsenic levels in drinking waters (Table 4). When MMSE score evaluation was made with individuals of age 65 or above, scores of 23 or below was found to be $86.1 \%$ in villages with high arsenic levels and $73.9 \%$ in villages with low arsenic levels. This difference was statistically significant $(p<0.05)$ (Table 4$)$.

Obesity was detected in $62.2 \%$ of all the surveyed individuals. Obesity status was found to be higher in the villages of Gölköy, Boğazköy, and Çitgöl when compared to the villages of Demirciköy and Öreyler (Table 5).

The average fruit and vegetable consumption values of the surveyed individuals were found to be $2.4 \pm 1.6$ and $2.4 \pm 1.2$ portions, respectively. While no significant differences were found in vegetable consumption $(p>0.05)$, statistically significant differences were detected between villages in terms of fruit consumption $(p<0.05)$. Daily fruit consumption in the villages of Demirciköy and Öreyler (i.e., $2.61 \pm 1.0$ portions) were found to be higher than their counterpart in Gölköy, Boğazköy, and Çitgöl (i.e., $2.34 \pm 1.3$ portions). The average daily water consumption of all surveyed individuals was determined to be $2.0 \pm 1.4 \mathrm{~L}$, and no statistically significant differences were found between the villages as shown in Table 6 . Similarly, arsenic exposure values were also calculated based on daily water intake, arsenic concentration in drinking water, and body weight and are presented in Table 6.

Questions regarding their dwellings were directed to all surveyed individuals in order to assess their living environments. Accordingly, it was found that individuals from 
Table 2 Distribution of the primary characteristics of surveyed individuals in villages, Simav-Kütahya, 2010-2011

\begin{tabular}{|c|c|c|c|c|c|c|}
\hline & \multicolumn{2}{|l|}{ Total } & \multicolumn{2}{|c|}{ Gölköy-Boğazköy-Çitgöl } & \multicolumn{2}{|c|}{ Öreyler-Demirciköy } \\
\hline & Number & $\%^{\mathrm{a}}$ & Number & $\%^{\mathrm{a}}$ & Number & $\%^{\mathrm{a}}$ \\
\hline \multicolumn{7}{|l|}{ Sex } \\
\hline Male & 522 & 52.0 & 312 & 50.8 & 210 & 54.0 \\
\hline Female & 481 & 48.0 & 302 & 49.2 & 179 & 46.0 \\
\hline \multicolumn{7}{|l|}{ Age group } \\
\hline $18-29$ & 105 & 10.5 & 68 & 11.1 & 37 & 9.6 \\
\hline $30-39$ & 111 & 11.1 & 71 & 11.6 & 40 & 10.3 \\
\hline $40-49$ & 172 & 17.2 & 107 & 17.5 & 65 & 16.8 \\
\hline $50-59$ & 228 & 22.8 & 142 & 23.2 & 86 & 22.2 \\
\hline $60-69$ & 156 & 15.6 & 96 & 15.7 & 60 & 15.5 \\
\hline $70-79$ & 161 & 16.1 & 95 & 15.5 & 66 & 17.1 \\
\hline$>80$ & 67 & 6.7 & 34 & 5.5 & 33 & 8.5 \\
\hline \multicolumn{7}{|l|}{ Education level } \\
\hline Secondary school and below & 849 & 84.6 & 534 & 87.0 & 315 & 81.0 \\
\hline High school and above & 154 & 15.4 & 80 & 13.0 & 74 & 19.0 \\
\hline \multicolumn{7}{|l|}{ Marital status } \\
\hline Never married & 76 & 7.6 & 47 & 7.7 & 29 & 7.5 \\
\hline Married/Living together & 774 & 77.2 & 488 & 79.5 & 286 & 73.5 \\
\hline Married/Living separated & 4 & 0.4 & 3 & 0.5 & 1 & 0.3 \\
\hline Widowed/Divorced & 149 & 14.9 & 76 & 12.4 & 73 & 18.8 \\
\hline \multicolumn{7}{|l|}{ Profession } \\
\hline Farmer & 370 & 36.9 & 227 & 37.0 & 143 & 36.8 \\
\hline Worker & 50 & 5.0 & 30 & 4.9 & 16 & 4.1 \\
\hline Housewife & 300 & 29.9 & 199 & 32.4 & 101 & 26.0 \\
\hline Merchant & 44 & 4.4 & 27 & 4.4 & 15 & 3.9 \\
\hline Others & 239 & 23.8 & 131 & 21.3 & 114 & 29.3 \\
\hline Total $^{\mathrm{b}}$ & 1003 & 100.0 & 614 & 100.0 & 389 & 100.0 \\
\hline
\end{tabular}

a Column \%

b Row \%

\begin{tabular}{|c|c|c|c|c|c|c|c|c|}
\hline \multirow[t]{3}{*}{ Villages } & \multicolumn{6}{|c|}{ Smoking status } & & \\
\hline & \multicolumn{2}{|c|}{ Active smoker } & \multicolumn{2}{|c|}{ Smoked, Quit } & \multicolumn{2}{|c|}{ Never smoked } & \multicolumn{2}{|l|}{ Total } \\
\hline & Number & $\%^{\mathrm{a}}$ & Number & $\%^{\mathrm{a}}$ & Number & $\%^{\mathrm{a}}$ & Number & $\%^{\mathrm{a}}$ \\
\hline Gölköy- & 129 & 21.0 & 124 & 20.2 & 361 & 58.8 & 614 & 61.3 \\
\hline \multicolumn{9}{|l|}{ Boğazköy-Çitgöl } \\
\hline Öreyler-Demirciköy & 107 & 27.6 & 91 & 23.5 & 190 & 49.0 & 388 & 38.7 \\
\hline Total & 236 & 23.6 & 215 & 21.5 & 551 & 55.0 & 1002 & 100.0 \\
\hline$p$ & 0.008 & & & & & & & \\
\hline
\end{tabular}

a Row \%

$p \chi^{2}$ test

Gölköy and Boğazköy had a relatively lower ratio for the presence of kitchen in the dwelling and this finding was found to be statistically significant $(p<0.05)$. On the other hand, no differences were found between the villages with regards to presence of bathroom and toilet inside the dwelling. Majority of the dwellings had a bathroom and toilet present inside the dwelling. The average number of rooms in the dwelling was calculated to be $4.11 \pm 1.3$ in both regions, and no statistically significant differences were detected $(p>0.05)$. Almost all dwellings in the study 
Table 4 Distribution of mini mental state examination scores of the surveyed individuals, Simav-Kütahya, 2010-2011
Table 5 Distribution of body mass index values and chronic disease status of the surveyed individuals, Simav-Kütahya, 2010-2011

\begin{tabular}{|c|c|c|c|c|c|}
\hline \multirow[t]{3}{*}{ Mini mental state exam score } & \multicolumn{4}{|l|}{ Villages } & \multirow[t]{3}{*}{$p$} \\
\hline & \multicolumn{2}{|c|}{ Gölköy-Boğazköy-Çitgöl } & \multicolumn{2}{|c|}{ Öreyler-Demirciköy } & \\
\hline & Number & $\%^{\mathrm{a}}$ & Number & $\%^{\mathrm{a}}$ & \\
\hline 24 and above & 285 & 46.9 & 204 & 53.1 & 0.055 \\
\hline 23 and under & 323 & 53.1 & 180 & 46.9 & \\
\hline \multicolumn{6}{|l|}{65 age under } \\
\hline 24 and above & 262 & 59.1 & 173 & 65.5 & 0.091 \\
\hline 23 and under & 181 & 40.9 & 91 & 34.5 & \\
\hline \multicolumn{6}{|l|}{65 age and above } \\
\hline 24 and above & 23 & 13.9 & 31 & 26.1 & 0.010 \\
\hline 23 and under & 142 & 86.1 & 88 & 73.9 & \\
\hline
\end{tabular}

\begin{tabular}{|c|c|c|c|c|c|}
\hline & \multicolumn{4}{|l|}{ Villages } & \multirow[t]{3}{*}{$p$} \\
\hline & \multicolumn{2}{|c|}{ Gölköy-Boğazköy-Çitgöl } & \multicolumn{2}{|c|}{ Öreyler-Demirciköy } & \\
\hline & Number & $\%^{\mathrm{a}}$ & Number & $\%^{\mathrm{a}}$ & \\
\hline \multicolumn{6}{|l|}{ Obesity status } \\
\hline Normal-BMI (18.9-24.9) & 198 & 33.0 & 172 & 45.4 & 0.0001 \\
\hline Over weight/Obese-BMI (25.0 and above) & 402 & 67.0 & 207 & 54.6 & \\
\hline \multicolumn{6}{|l|}{ Chronic Disease Status ${ }^{\mathbf{b}}$} \\
\hline Not Present & 385 & 62.7 & 223 & 57.3 & 0.089 \\
\hline Present & 229 & 37.3 & 166 & 42.7 & \\
\hline \multicolumn{6}{|l|}{$p \chi^{2}$ test, $B M I$ Body mass index $\left(\mathrm{kg} / \mathrm{m}^{2}\right)$} \\
\hline a Column $\%$ & & & & & \\
\hline
\end{tabular}

Table 6 Statistical summary of daily water intake and arsenic exposure via oral route, Simav-Kütahya, 2010-2011

\begin{tabular}{|c|c|c|c|c|}
\hline \multirow[t]{2}{*}{ Village } & \multicolumn{2}{|c|}{ Daily water intake (L) } & \multicolumn{2}{|c|}{ Daily arsenic intake via oral route $(\mu \mathrm{g} / \mathrm{kg} /$ day $)$} \\
\hline & Average $\pm \mathrm{SD}$ & Median (Min-Max) & Average $\pm \mathrm{SD}$ & Median (Min-Max) \\
\hline Gölköy & $2.2 \pm 1.5$ & $1.5(0.2-8.0)$ & $7.7 \pm 5.2$ & $5.89(0.71-37.39)$ \\
\hline Boğazköy & $2.2 \pm 1.4$ & $2.0(0.2-10.0)$ & $7.4 \pm 4.5$ & $6.5(0.69-33.03)$ \\
\hline Öreğler & $2.0 \pm 1.2$ & $2.0(0.25-8.0)$ & $0.03 \pm 0.017$ & $0.026(0.0-0.10)$ \\
\hline Demirciköy & $1.9 \pm 1.1$ & $2.0(0.2-6.0)$ & $0.03 \pm 0.02$ & $0.032(0.0-0.12)$ \\
\hline Çitgöl & $1.7 \pm 1.5$ & $1.4(0.2-15.0)$ & $1.02 \pm 0.87$ & $0.80(0.12-9.19)$ \\
\hline Villages with low arsenic levels in water supply & $1.9 \pm 1.1$ & $2.0(0.2-15.0)$ & $0.03 \pm 0.02$ & $0.029(0.0-0.12)$ \\
\hline Villages with high arsenic levels in water supply & $2.0 \pm 1.5$ & $1.5(0.2-15.0)$ & $5.4 \pm 5.04$ & $4.1(0.12-37.39)$ \\
\hline Overall & $2.0 \pm 1.4$ & $2.0(0.2-15.0)$ & $3.3 \pm 4.7$ & $0.84(0.0-37.39)$ \\
\hline
\end{tabular}

area were found to be connected to the water supply network. The source of drinking water supply, on the contrary, showed differences between the two regions. As shown in
Table 7, 88.2\% of the inhabitants of the villages of Öreyler and Demirciköy consumed drinking water from the water supply network that is mainly served by natural springs in 
Table 7 Distribution of water resource used by the surveyed individuals, Simav-Kütahya, 2010-2011

\begin{tabular}{|c|c|c|c|c|c|}
\hline \multirow[t]{3}{*}{ Water resource } & \multicolumn{4}{|l|}{ Villages } & \multirow[t]{3}{*}{$p$} \\
\hline & \multicolumn{2}{|c|}{ Gölköy-Boğazköy-Çitgöl } & \multicolumn{2}{|c|}{ Öreyler-Demirciköy } & \\
\hline & Number & $\%^{\mathrm{a}}$ & Number & $\%^{\mathrm{a}}$ & \\
\hline Village well and distribution system & 386 & 59.8 & 352 & 88.2 & 0.0001 \\
\hline Neighborhood fountains & 206 & 31.9 & 40 & 10.0 & \\
\hline Individual wells & 3 & 0.5 & 1 & 0.3 & \\
\hline Bottled water & 51 & 7.9 & 6 & 1.5 & \\
\hline Total & 646 & 100.0 & 399 & 100.0 & \\
\hline
\end{tabular}

${ }^{a}$ Percentage within the total number of individuals who answered the question the mountains, whereas $10 \%$ consumed drinking water from neighborhood fountains. On the contrary, only $59.7 \%$ of the inhabitants of the villages of Gölköy, Boğazköy, and Çitgöl consumed drinking water from the water supply network that is mainly served by the wells drilled in the arsenic-containing alluvial aquifer, whereas about $30 \%$ consumed drinking water from neighborhood fountains and about $8 \%$ consumed bottled water purchased from supermarkets. Bottled water consumption was found to be higher in the village of Çitgöl. The relatively low consumption percentages from the water supply networks in Gölköy, Boğazköy, and Çitgöl are associated with the previous complaints from the quality of water. The relatively high percentage of bottled water use in these villages is another indication for low water quality of the water supply network.

$39.4 \%$ of the individuals surveyed had at least one chronic illness including but not limited to the diseases of the cardiovascular system, respiratory system, diabetes mellitus and endocrine system, and gastrointestinal system as well as skin and internal organ neoplasms. Although no statistically significant differences were detected between the villages, the percentage of occurrence of chronic diseases was found to be higher in the villages of Demirciköy and Öreyler (Table 8).

When the distribution of chronic diseases was analyzed, circulatory system diseases were found to be highest in number (Table 8 ) followed by endocrine, metabolic, and gastrointestinal system diseases. However, no significant differences between villages were observed. Cancers, on the other hand, were calculated to have a percentage of $2.1 \%$. Of the 17 cases of cancer identified as a result of the interviews, two were myoma, breast, and skin cancers. Both of these cases were recorded in Öreyler and Demirciköy. There were eight cases of uterus and ovarian cancers, three of which were in Gölköy, Boğazköy, and Çitgöl and the remaining five were in Demirciköy and Öreyler. Three cases of colon cancer and one case of lung cancer were detected in Gölköy. One case of skin cancer was found in Boğazköy, and one case of stomach cancer were found in Çitgöl. Finally, one case of prostate cancer was found in Öreyler.

The individual arsenic exposure via oral route is considered among the etiological factors for the presence of chronic diseases. However, it is not accurate to associate the occurrence of these diseases to a single factor. The individual exposure figures calculated by using the arsenic concentrations of the water supply, the individual water consumption value, and the body weight of the individual are used in the logistic regression analysis as shown in Table 9. The risk associated with arsenic exposure was computed to be 1.046 (95\% CI 1.010-1.083).

\section{Discussions}

In a water quality monitoring study conducted in 2005 , Simsek and Gunduz (2007) and Gunduz et al. (2010) reported elevated arsenic levels in the drinking water supplies of the villages of Gölköy, Boğazköy, and Çitgöl in Simav district. The results of the samples collected from the water supply wells of these villages ranged between 27 and $177.2 \mu \mathrm{g} / \mathrm{L}$. While the extent and duration of exposure was uncertain, the results of this study were considered to be an alarm bell for the inhabitants of these villages and further research was deemed necessary. The local administrators, however, stated that the minimum duration of exposure was believed to be about 20 years.

In the light of information presented above, this study was aimed to determine the presence of chronic diseases and the causes of deaths in villages that were exposed to high levels of arsenic through drinking water for a moderately long amount of time. While no statistically significant differences were observed in death causes between the villages, it was interesting to find out that all cases of potentially arsenic-related cancer (bladder, liver, and lung) deaths took place in villages with high arsenic levels in drinking water supplies (Gunduz et al. 2012). However, the relatively small populations of these villages and the uncertainties associated with the duration and extent of 
Table 8 Distribution of chronic diseases diagnosed by a doctor that require continuous use of mediations, Simav-Kütahya, 2010-2011

\begin{tabular}{|c|c|c|c|c|c|c|c|}
\hline \multirow[t]{2}{*}{ ICD-10 Main Diagnosis Codes } & \multirow[t]{2}{*}{ Code } & \multicolumn{2}{|l|}{ Total } & \multicolumn{2}{|c|}{$\begin{array}{l}\text { Gölköy-Boğazköy- } \\
\text { Çitgöl }\end{array}$} & \multicolumn{2}{|c|}{$\begin{array}{l}\text { Öreyler- } \\
\text { Demirciköy }\end{array}$} \\
\hline & & Number & $\%^{\mathrm{a}}$ & Number & $\%^{\mathrm{a}}$ & Number & $\%^{\mathrm{a}}$ \\
\hline Certain infectious and parasitic diseases & A00-B99 & 6 & 0.8 & 3 & 0.6 & 3 & 0.9 \\
\hline Neoplasms (Cancers) & C00-D48 & 17 & 2.1 & 9 & 1.9 & 8 & 2.5 \\
\hline $\begin{array}{l}\text { Diseases of the blood and blood-forming organs } \\
\text { and certain disorders involving the immune mechanism }\end{array}$ & D50-D89 & 7 & 0.9 & 2 & 0.4 & 5 & 1.5 \\
\hline Endocrine, nutritional and metabolic diseases & E00-E90 & 143 & 18.0 & 87 & 18.5 & 56 & 17.3 \\
\hline Mental and behavioral disorders & F00-F99 & 12 & 1.5 & 8 & 1.7 & 4 & 1.2 \\
\hline Diseases of the nervous system & G00-G99 & 3 & 0.4 & 1 & 0.2 & 2 & 0.6 \\
\hline Diseases of the eye and adnexa & H00-H59 & 6 & 0.8 & 6 & 1.3 & 0 & 0.0 \\
\hline Diseases of the ear and mastoid process & H60-H95 & 1 & 0.1 & 1 & 0.2 & 0 & 0.0 \\
\hline Diseases of the circulatory system & I00-I99 & 288 & 36.3 & 174 & 37.0 & 114 & 35.2 \\
\hline Diseases of the respiratory system & J00-J99 & 35 & 4.4 & 20 & 4.3 & 15 & 4.6 \\
\hline Diseases of the digestive system & K00-K93 & 132 & 16.6 & 69 & 14.7 & 63 & 19.4 \\
\hline Diseases of the skin and subcutaneous tissue & L00-L99 & 3 & 0.4 & 1 & 0.2 & 2 & 0.6 \\
\hline Diseases of the musculoskeletal system and connective tissue & M00-M99 & 91 & 11.5 & 56 & 11.9 & 35 & 10.8 \\
\hline Diseases of the genitourinary system & N00-N99 & 12 & 1.5 & 6 & 1.3 & 6 & 1.9 \\
\hline $\begin{array}{l}\text { Symptoms, signs, and abnormal clinical and laboratory } \\
\text { findings, not elsewhere Classified }\end{array}$ & R00-R99 & 38 & 4.8 & 27 & 5.7 & 11 & 3.4 \\
\hline Total & & 794 & 100.0 & 470 & 100.0 & 324 & 100.0 \\
\hline
\end{tabular}

a Column \%

Table 9 Logistic regression analysis ${ }^{\mathrm{a}}$ of risk factors related to chronic diseases ${ }^{\mathrm{b}}$, Simav-Kütahya, 2010-2011

\begin{tabular}{|c|c|c|c|c|}
\hline & B & OR & $95 \% \mathrm{CI}$ & $p$ \\
\hline Individual arsenic exposure via oral route $(\mu \mathrm{g} / \mathrm{kg} / \mathrm{day})$ & 0.045 & 1.046 & $1.010-1.083$ & 0.01 \\
\hline Village group [Gölköy—Boğazköy—Çitgöl (1)/Demirciköy—Öreyler (0)] & -0.632 & 0.531 & $0.378-0.747$ & 0.0001 \\
\hline Obesity [Over weight/Obese-BMI (25.0 and high (1)/Normal-BMI (18.9-24.9)] & 0.704 & 2.022 & $1.509-2.687$ & 0.0001 \\
\hline Cigarette smoking [Used at least once $(1) /$ Never used $(0)$ ] & -0.651 & 0.522 & $0.394-0.690$ & 0.0001 \\
\hline Salt consumption [High (1)/Normal or low $(0)]$ & -0.709 & 0.492 & $0.378-0.747$ & 0.001 \\
\hline Constant & -0.261 & 0.770 & & 0.106 \\
\hline
\end{tabular}

${ }^{a}$ Backward conditional logistic regression analysis

Dependent variable: Presence of chronic disease

Independent variables: Sex, village, individual arsenic exposure via oral route, obesity, history of chronic disease presence in the family, cigarette smoking and exposure to second hand smoke, salt consumption, and total length of time lived in the village

b Presence of one or more of chronic diseases (cardiovascular diseases, chronic respiratory diseases, diabetes mellitus and endocrine system diseases, cancers, and disease of the gastrointestinal system) diagnosed by a doctor that require continuous use of medications

$B M I$ body mass index $\left(\mathrm{kg} / \mathrm{m}^{2}\right), B$ a constant, $O R$ odds ratio, $C I$ confidence interval

exposure to arsenic prevented Gunduz et al. (2015) to reach a definitive conclusion.

The results of this study revealed that a chronic disease was present in $39.4 \%$ of all the individuals surveyed in the area. While no statistically significant differences were detected between the two regions with regards to chronic disease distribution, the frequencies of chronic diseases were found to be higher in villages with high arsenic levels in drinking water supplies. A logistic regression analysis was made to find out the determining risk factors of chronic diseases. The results of logistic regression analysis only revealed a statistically significant correlation for obesity. The lower risk factors for cigarette smoking and salt consumption were believed to be related to the type of chronic disease and the distribution of its etiological factors. With respect to the distribution of chronic diseases, cardiovascular system diseases and endocrine system diseases were found to be dominant in the study area. However, no 
significant differences were observed between the villages. When the distribution of cancers was analyzed, it was seen that cases of lung, colon, and stomach cancers were seen in villages with high arsenic levels, whereas cases of other cancers were similarly distributed between the two regions.

In general, it is difficult to describe the causes of chronic diseases. Numerous risk factors are influential in the etiology of these diseases. Genetic heritage, biological factors, nutrition preferences, physical activity level, harmful habits, and environmental factors are jointly influential in the occurrence of chronic diseases. Thus, it is very difficult to describe the etiologies of chronic diseases through crosssectional epidemiological studies. In this study, a number of personal and environmental factors were questioned to assess the potential risks of chronic disease occurrence. The primary indicators such as age, educational status, and profession were found to demonstrate a similar distribution among the two regions.

Smoking is generally accepted to be the most significant risk factor for chronic diseases causing respiratory illnesses, cancers, and cardiovascular diseases. When the data on smokers were analyzed, it was found that the number of smokers was higher in the villages of Öreyler and Demirciköy. This difference between the two regions could explain the distribution differences of chronic diseases in the two regions. Alcohol use is another important risk factor for chronic diseases. In this study, the number of individuals who have never used alcohol throughout their lives were found to be higher in Gölköy, Boğazköy, and Çitgöl. The frequency of chronic diseases was also consistent with alcohol use. However, the amount of alcohol use was not questioned in this study to reach quantitative results correlating the amount of alcohol consumed with the presence of chronic diseases. It is also important to note that the study area is a region where people rarely consume alcohol due to religious concerns. In addition, percentage of people who consume alcohol is even lower in villages with high As levels, which made us believe that the presence of chronic diseases due to alcohol consumption is minimal and can be ignored for the study area.

Obesity is another important risk factor influencing the occurrence of chronic diseases. In this study, obesity was found to increase the risk of chronic diseases 2.022 (95\% CI 1.509-2.687) times. Moreover, obesity was higher in the villages of Gölköy, Boğazköy, and Çitgöl. There are, however, other factors such as smoking, alcohol use, and other nutritional preferences that could explain why chronic diseases were higher in a number in the villages of Öreyler and Demirciköy, where arsenic levels were relatively lower. It should also be noted that this study was based on the results of a questionnaire that primarily questioned the presence of a doctor-diagnosed chronic diseases in the surveyed individual. Some of these individuals may not be aware of their illnesses, which in turn could create a selective bias.

While individual arsenic exposure via oral route is considered to be among the etiological factors for the presence of chronic diseases, it is not accurate to associate the occurrence of these diseases to a single factor. This is verified by the low level of relation obtained as shown in Table 9. High number of factors influencing the relationships further complicates the problem. Most of the chronic diseases have multi-factors in their etiologies, and accurate data during their long-term exposures are typically missing. The cross-sectional nature of this study prevented an accurate identification of factors influential in the etiology of chronic diseases. Daily water consumption was considered to be the only route of exposure, which brings in an additional source of uncertainty occurring from other exposure pathways. Furthermore, the relatively low arsenic values in drinking water supplies water when compared to their counterparts in Bangladesh and Taiwan were also critical for not obtaining strong correlations. Overall, all of these factors were effective in this low level of relation (1.046: 95\% CI 1.010-1.083). Nevertheless, the positive relation between arsenic exposure and chronic disease presence still sheds a light on our overall understanding of arsenic-chronic disease connection at the lower spectrum of arsenic concentrations.

No significant differences were detected in terms of daily water consumption and other nutritional preferences between the two regions excluding daily fruit consumption. It was found that fruit consumption was lower in villages with high arsenic levels in drinking water supplies. Furthermore, the use of neighborhood fountains and bottled water was higher in Gölköy, Boğazköy, and Çitgöl. In Gölköy and Boğazköy, in particular, the use of neighborhood fountains for drinking water supply was relatively higher.

In this study, a MMSE test was conducted on all surveyed individuals to determine their cognitive functions. While the results of this test revealed lower scores in villages with high arsenic levels in drinking water supplies, no statistically significant differences were observed between the two regions (Table 4). The study conducted by Gong et al. (2011) documented a similar correlation between MMSE scores and arsenic levels, the average age of surveyed individuals and arsenic levels. The MMSE score and the arsenic levels reported in Gong et al. (2011) were lower compared to the study presented herein. Gong et al. (2011) also reported harmful effects of arsenic on neurological processes. In line with this finding, it is also thought that arsenic is also influential in the change that plays a role in the pathogenesis of Alzheimer disease as a result of certain cellular damage in neurons. Arsenic exposure also has a remarkable influence on the neurocognitive functions. 
Gong et al. (2011) further emphasized disinhibitory effects on memory and learning skills based on some animal models. In our study, the MMSE scores for the age group $65+$ were found to be statistically significantly lower in villages with higher arsenic levels in drinking water. Further neurological assessments and research is necessary to link this finding with dementia or Alzheimer disease. Nevertheless, lower MMSE scores in 65+ age group might likely be an alarm bell for a possible connection to arsenic exposure based on the assessment of current literature. The extended period of exposure in the $65+$ age group is a supportive finding for this connection in the study area.

When all these variables were jointly analyzed, it was concluded that the differences in chronic diseases between the two regions were mostly associated with smoking and alcohol use. The reason why smoking was not determined to be a risk factor for chronic diseases was associated with low smoker ratio in females. The results of the present study revealed that only $5 \%$ of all female individuals surveyed smoke. However, the occurrence of chronic diseases in females was found to be $60 \%$, which was the reason for the confusing outcome that smoking was not a risk factor.

Overall, no major differences were observed in this study with regards to the distribution of chronic diseases. However, when cancers were concerned, the occurrence of all cases of lung, colon, and stomach cancers was observed in villages with high arsenic levels in drinking water supplies. While this finding was not a statistically strong outcome, it should be noted that, in another research conducted for analyzing the death causes in the same area, deaths due to bladder, liver, and lung cancers were also observed in these villages with high arsenic levels (Gunduz et al. 2015). Arsenic presence in drinking water is considered to be a significant risk factor for all of these reported cases of cancers. The relatively lower arsenic concentrations in the study area compared to other parts of the world such as Taiwan and Bangladesh and the uncertainties in the duration of exposure were influential in not reaching stronger conclusions. Nevertheless, the results of this study still revealed that an arsenic-related influence could not be totally disregarded for the occurrence of chronic diseases.

Regional health data are quite limited in Turkey. Thus, it is not possible to discuss the health statistics obtained from this research with the regional and state-wide health conditions. The death statistics, on the other hand, are available at provincial and state-wide levels. According to the death statistics of Kütahya province where Simav district is located, cardiovascular disease, cancers, and respiratory system diseases are the first three causes of death with respective ratios of $44.6,17.4$, and $10.9 \%$. This order is similar state-wide (Turkey) with corresponding ratios of 37.9, 21.1, and 9.7\% (TUIK 2016). Furthermore, the death statistics compiled within the scope of this research also verified a similar pattern with respective death ratios of 44.0, 15.2, and 5.7\% (Gunduz et al. 2015). The reason for relatively low occurrences of respiratory system-related deaths is primarily related to good air quality of the study area with no major industrial emission sources releasing toxic gaseous pollutants. Despite lack of data, the distribution of chronic diseases is also thought to follow a parallel pattern and is not likely to not show major deviations at the local, provincial, and state-wide levels.

\section{Conclusions}

This study was intended to determine the relationships between the occurrences of chronic diseases in villages with high arsenic levels in drinking water supplies. Although strong correlations were not found, it is known that cross-sectional epidemiological studies such as the one conducted in this research was not alone sufficient to explain the relationship between arsenic exposure and the etiology of chronic disease occurrence. Longer duration cohort studies are necessary to achieve more concrete results. Nevertheless, when cancer occurrence and cancerrelated deaths in the villages with long-term arsenic exposure were analyzed, it could be seen that arsenic was a factor in human health in the study area.

Following the first detection of high arsenic presence in the region, safer resources of water supply were put into service for the villages of Gölköy and Boğazköy based on the results of this study. For the village of Çitgöl, on the other hand, a new arsenic treatment plant was constructed and put into service. Considering the problematic geological structure of the region, continuous water quality monitoring activities should continue in the future, and human health status of the area should be kept under control by follow-up health surveys to obtain an overall disease inventory, which could later be used to provide a time-dependent assessment of the situation.

Funding This study is funded by the Scientific and Technological Research Council of Turkey (TÜBITAK) through project number 109Y029. The authors express their gratitude to the local people of the villages of Çitgöl, Boğazköy, Gölköy, Demirciköy, and Öreyler for their support and hospitality during field work.

\section{Compliance with ethical standards}

Conflict of interest The authors do not declare any actual or potential conflict of interest including any financial, personal, or other relationships with other people or organizations that could inappropriately influence this work.

Ethical Approval The ethical approval for this study was issued by the Clinical and Laboratory Research Ethical Committee of Dokuz 
Eylul University with the document dated 21/01/2009 and numbered B.20.2.DEU.0.01.00.00/1417.

\section{References}

Chen CJ (2010) Health hazards of arsenic drinking water. Arsenic in Geosphere and Human Diseases. As 2010. Arsenic in the environment proceedings, pp 251-252

Chiou HY, Chiou ST, Hsu YH, Chou YL, Tseng CH, Wei ML, Chen CJ (2001) Incidence of transitional cell carcinoma and arsenic in drinking water: a follow-up study of 8,102 residents in an arseniasis-endemic area in Northeastern Taiwan. Am J Epidemiol 153(5):411-418. doi:10.1093/aje/153.5.411

Chou CH, De Rosa CT (2003) Case studies-Arsenic. Int J Hyg Environ Health 206:381-386. doi:10.1078/1438-4639-00234

Dogan M, Dogan AU, Celebi C, Baris YI (2005) Geogenic arsenic and a survey of skin lesions in the Emet Region of Kütahya, Turkey. Indoor Built Environ 14(6):533-536. doi:10.1177/ 1420326X0506121

Ferreccio C, González C, Milosavjlevic V, Marshall G, Sancha AM, Smith AH (2000) Lung cancer and arsenic concentrations in drinking water in Chile. Epidemiology 11(6):673-679. doi:10. 1097/00001648-200011000-00010

George CM, Sima L, Arias MHJ, Mihalic J, Cabrera LZ, Danz D, Checkley W, Gilman RH (2014) Arsenic exposure in drinking water: an unrecognized health threat in Peru. Bull World Health Organ 92:565-572. doi:10.2471/BLT.13.128496

Gong G, Hargrave KA, Hobson V, Spallholz J, Boylan M, Lefforge D, O’Byrant SE (2011) Low-level groundwater arsenic exposure impacts cognition: a project FRONTIER study. J Environ Health 74(2):16-22

Gunduz O, Simsek C, Hasozbek A (2010) Arsenic pollution in the groundwater of Simav Plain, Turkey: its impact on water quality and human health. Water Air Soil Pollut 205:43-62. doi:10. 1007/s11270-009-0055-3

Gunduz O, Elci A, Simsek C, Baba A, Bakar C, Gurleyuk H, Mutlu M, Cakir A (2012) Final Report. TUBITAK Project No: 109Y029 Izmir. (in Turkish)

Gunduz O, Bakar C, Simsek C, Baba A, Elci A, Gurleyuk H, Mutlu M, Cakir A (2015) Statistical analysis of death causes (2005-2010) in villages with high arsenic levels in drinking water supplies of Simav plain, Turkey. Arch Environ Occup Health 70:35-46. doi:10.1080/19338244.2013.872076
Güngen C, Ertan T, Eker E, Yaşar R (2002) Standardize mini mental test'in türk toplumunda hafif demans tanisinda geçerlilik ve güvenilirliği. Türk Psikiyatri Dergisi 13(4):273-281 (in Turkish)

Guo H (2011) Age adjustment in ecological studies: using a study on arsenic ingestion and bladder cancer as an example. BMC Public Health 11(820):1. doi:10.1186/1471-2458-11-820

Hughes MF, Beck BD, Chen Y, As Lewis, Thomas DJ (2011) Arsenic exposure and toxicology: a historical perspective. Toxicol Sci 123(2):305-332. doi:10.1093/toxsci/kfr184

Lemeshow S, Hosmer DW Jr, Klar J, Lwanga SK (1990) Adequacy of sample size in health studies. Wiley, West Sussex

Liaw J, Marshall G, Yuan Y, Ferreccio C, Steinmaus C, Smith AH (2008) Increased childhood liver cancer mortality and arsenic in drinking water in Northern Chile. Cancer Epidemiol Biomarkers Prev 17(8):1982-1987. doi:10.1158/1055-9965.EPI-07-2816

Meliker JR, Wahl RL, Cameron LL, Nriagu JO (2007) Arsenic in drinking water and cerebrovascular disease, diabetes mellitus, and kidney disease in Michigan: a standardized mortality ratio analysis. Environ Health 6:4. doi:10.1186/1476-069X-6-4

Rahman M, Tondel M, Ahmad SA, Axelson O (1998) Diabetes mellitus associated with arsenic exposure in Bangladesh. Am J Epidemiol 148(2):198-203

Saint-Jacques N, Parker L, Brown P, Dummer TJB (2014) Arsenic in drinking water and urinary tract cancers: a systematic review of 30 years of epidemiological evidence. Environ Health 13:44. doi:10.1186/1476-069X-13-44

Simsek C, Gunduz O (2007) IWQ index: a GIS-integrated technique to assess irrigation water quality. Environ Monit Assess 128(1-3):277-300. doi:10.1007/s10661-006-9312-8

States JC, Srivastava S, Chen Y, Barchowsky A (2009) Arsenic and cardiovascular disease. Toxicol Sci 107(2):312-323. doi:10. 1093/toxsci/kfn236

TUIK (2016) Death Statistics of Province and District Centers in 2010, 2011 and 2012. Turkish Statistical Institute, Ankara. http:// www.tuik.gov.tr/PreHaberBultenleri.do?id=15847 (in Turkish)

Wedepohl KH (1995) The Composition of the continental crust. Geochim Cosmochim Acta 59(7):1217-1232. doi:10.1016/00167037(95)00038-2

WHO (2011) World Health Organization guidelines for drinking water quality, 4th edn, p 541 ISBN 9789241548151

WHO (2015) World Health Organization fact sheet on noncommunicable diseases http://www.who.int/mediacentre/factsheets/ fs355/en/ 